\title{
Neuroprotective Effects of Anthraquinones from Rhubarb in Central Nervous System Diseases
}

\author{
Xun Li, ${ }^{1}$ Shifeng Chu, ${ }^{2}$ Yinjiao Liu, ${ }^{1}$ and Naihong Chen ${ }^{10}{ }^{1,2}$ \\ ${ }^{1}$ College of Pharmacy, Hunan University of Chinese Medicine, Changsha 410208, China \\ ${ }^{2}$ Institute of Materia Medica, Chinese Academy of Medical Sciences and Peking Union Medical College, Beijing 100050, China \\ Correspondence should be addressed to Naihong Chen; chennh@imm.ac.cn
}

Received 22 January 2019; Accepted 21 April 2019; Published 16 May 2019

Academic Editor: Carmen Mannucci

Copyright (c) 2019 Xun Li et al. This is an open access article distributed under the Creative Commons Attribution License, which permits unrestricted use, distribution, and reproduction in any medium, provided the original work is properly cited.

\begin{abstract}
Rhubarb is a well-known traditional Chinese medicine; it has been used in China for thousands of years. Rhubarb anthraquinones are the major medicinal ingredients derived from rhubarb including emodin, aloe-emodin, chrysophanol, rhein, physcion, and danthron. These different anthraquinone derivatives alone or in combination play a therapeutic role in central nervous system diseases (CNSD), such as cerebral ischemic stroke, intracerebral hemorrhage, traumatic brain injury, brain tumor, Alzheimer's disease, depression, and others. We review the experimental studies on these six anthraquinones in the treatment of CNSD by consulting literature published in the last 20 years in PubMed and then give a future perspective on it. In the end of this paper some deficiencies related to these studies also have been pointed out.
\end{abstract}

\section{Introduction}

Rhubarb (Da Huang) is dried rhizomes and roots of Rhubarb palmatum L, Rheum tangguticum Maxim. ex Balf, or Rheum officinale Baill from Polygonaceae family [1]. It is one of the oldest and most widely known Chinese herbal medicines, first reported in Shen Nong's Materia Medica from Han Dynasty [2]. Rhubarb is normally used as an effective laxative, and many Chinese herbal prescriptions contain it. The main effective ingredients of rhubarb are anthraquinone derivatives including emodin (1,3,8-trihydroxy-6-methylanthraquinone, $2.6 \%$ ), aloe-emodin (1,8-dihydroxy-3-hydroxyl-methylanthraquinone, $1.8 \%$ ), chrysophanol (1,8-dihydroxy-3-methyl-anthraquinone, 1.9\%), rhein (1,8-dihydroxy-3-carboxyanthraquinone, 1.9\%), physcion (1,8-dihydroxy-3-methyl-6-methoxy anthraquinone, $0.8 \%$ ), and danthron (1,8-dihydroxy-9,10-anthraquinone, <0.2\%) (Figure 1) [3]. These anthraquinone derivatives are also used as the quality control standard of rhubarb according to the Chinese Pharmacopoeia [4, 5]. Modern pharmacological studies indicated that these anthraquinones possess a wide spectrum of pharmacological properties, such as antiinflammatory, antioxidant, antitumor, and antivirus [6-11].
Cerebral ischemic stroke (CIS), intracerebral hemorrhage (ICH), traumatic brain injury (TBI), brain tumor, Alzheimer's disease (AD), and depression are common diseases of central nervous system. Patients with these diseases usually end up with death or disability, and the treatment of these diseases consumes huge amounts of social wealth [12-16]. Chinese herbal medicines have attracted widespread attention because it has the lower risk and less cost than many other conventional treatments [17]. In recent years, emerging experimental researches about these anthraquinones in the treatment of central nervous system diseases (CNSD) have been done, but there are no relevant reviews which have been published so far. So the purpose of this review is to give a comprehensive summary and analysis of various major anthraquinones from rhubarb in the treatment of CNSD during the past two decades.

\section{Neuroprotective Effects of Anthraquinones from Rhubarb in Different CNSD}

2.1. Cerebral Ischemic Stroke. The occlusion of vascular and blockage of cerebral blood flow, brain ischemia and 
<smiles>Cc1cc(O)c2c(c1)C(=O)c1cc(O)cc(O)c1C2=O</smiles><smiles>O=C(O)c1cc(O)c2c(c1)C(=O)c1cccc(O)c1C2=O</smiles>

Rhein<smiles>CC(C)(C)O</smiles><smiles>Cc1cc(O)c2c(c1)C(=O)c1cc(C)cc(O)c1C2=O</smiles>

Physcion<smiles>Cc1cc(O)c2c(c1)C(=O)c1c(O)cccc1C2=O</smiles><smiles>O=C1c2cccc(O)c2C(=O)c2c(O)cccc21</smiles>

Danthron

FIgURE 1: Chemical structures of anthraquinone derivatives in rhubarb.

hypoxia, and necrosis of brain tissue are commonly caused by CIS; these results eventually lead to neurological dysfunction [18]. Neurobiochemical and molecular biological mechanisms lead to neuronal damage in CIS including postischemic inflammation, oxidative stress, reperfusion injury, neuronal apoptosis, excitotoxicity, blood-brain barrier (BBB) dysfunction, microvascular injury, etc. [19, 20]. Rhubarb anthraquinones which play a neuroprotective role in CIS are mainly emodin, chrysophanol, and rhein, or different rhubarb anthraquinones act together. Different anthraquinones with the relevant mechanisms will be introduced in four parts as follows.

Firstly, emodin exerts neuroprotective effects in CIS by maintaining the integrity of $\mathrm{BBB}$, reducing inflammation and inhibiting apoptosis [18, 21-24]. Yan Li et al. [18] found that emodin improved the neurological deficit scores (NDS), reduced $\mathrm{BBB}$ permeability, and decreased the infarction area in cerebral ischemia/reperfusion (I/R) model rats; these results were probably due to the inhibitory effect of emodin against the expressions of connexin $43(\mathrm{Cx} 43)$ and aquaporin 4 (AQP4). Cx43 belongs to a member of membrane protein family, it composes the basic structure and function of intercellular gap junctions [25], and AQP4 is a kind of membrane water channel protein that plays an important role in cerebral edema and brain water balance [26]. In another in vivo study, emodin inhibited cascade inflammatory reaction by increasing the level of growth transforming factor- $\beta$ (TGF$\beta$ ) and depressing the levels of tumor necrosis factor- $\alpha$ (TNF$\alpha$ ), interleukin-1 $\beta$ (IL-1 $\beta$ ), and intercellular cell adhesion molecule-1 (ICAM-1) and thus improved the neurological symptom evaluation score, brain water ratio, and cerebral infarction area in model rats [21]. On the other hand, a number of in vitro studies have demonstrated that emodin could inhibit neuronal apoptosis [22, 23, 27]. Sung Min Ahn et al. [22] reported that emodin reduced glutamate-induced apoptosis by increasing B-cell lymphoma-2 (Bcl-2) expression and decreasing the expressions of caspase- 3 and Bax in HT22 cells; what is more, it also increased the expression of mature brain-derived neurotrophic factor (BDNF) and the phosphorylations of Akt and cAMP response element binding protein (CREB) and therefore improved behavioral function in photothrombotic ischemic mice. Similarly, Liu T et al. [23] suggested that emodin inhibited hydrogen peroxide $\left(\mathrm{H}_{2} \mathrm{O}_{2}\right)$-induced apoptosis in primary rat cortical neurons. Besides, it has been found that emodin could inhibit neuronal apoptosis and alleviate the injury of PC12 nerve cells after oxygen-glucose deprivation via increasing the expression of activin $\mathrm{A}[24]$, which belongs to transforming growth factor $\beta 1$ signal transduction system superfamily and exerts neuroprotective effect $[27,28]$.

Secondly, the neuroprotective mechanisms of chrysophanol (CHR) in CIS are mainly associated with antinitrosative/oxidative, anti-inflammatory, and antiapoptosis [29-31]. Yongmei Zhao et al. [29] suggested that CHR could suppress NO-associated neuronal cell death through attenuating the levels of nitrite plus nitrate $\left(\mathrm{NO}_{\mathrm{x}}{ }^{-}\right)$and 3nitrotyrosine (3-NT) and decrease cleaved caspase-3 protein expression. Besides, CHR increased the total superoxide dismutase (SOD) and manganese-dependent SOD (MnSOD) activities and inhibited reactive oxygen species (ROS) generation in the cerebral I/R model. Meanwhile, Nan Zhang et al. [30] reported that CHR inhibited inflammatory response via reducing the expressions of IL- $1 \beta$, caspase- 1 as well as NALP3 and then decreased neurological deficits, infarct volume, brain edema, and BBB permeability in I/R mice. NALP3 belongs to NALP3 inflammasome consisted of NACHT domain-, leucine-rich repeat-, and pyrin domain-containing protein 3 (NALP3), the adaptor protein apoptosis-associated speck-like protein (ASC), and caspase-1, and the function of it is to activate IL- $1 \beta$ then triggers inflammatory cascade [32, 33]. Similarly, CHR also exhibited anti-inflammatory actions by attenuating the expressions of TNF- $\alpha$, IL- $1 \beta$, and NF$\kappa \mathrm{B}$ p65 and finally improved the survival rate, neurological assessment, and motor function in middle cerebral artery occlusion mice [34]. What is more, CHR could inhibit inflammatory response and neuronal apoptosis in I/R injury mice by attenuating the expression of endoplasmic reticulum (ER) stress-related factors including glucose-regulated protein 78 
(GRP78), phosphorylated eukaryotic initiation factor $2 \alpha$ (p-eIF2 $\alpha$ ), CCAAT-enhancer-binding protein homologous protein (CHOP), and caspase-12 as well as inhibitory $\kappa \mathrm{B}-\alpha$ $(\mathrm{I} \kappa \mathrm{B}-\alpha)$ and the inhibitor of NF- $\kappa \mathrm{B}$ [31].

Thirdly, QIPENG ZHAO et al. [35] reported that rhein exhibited neuroprotective effects by inhibiting oxidative stress and apoptosis. Rhein could decrease malondialdehyde (MDA) level and enhance the activities of SOD, catalase (CAT), and glutathione peroxidase (GSH-Px). Moreover, rhein markedly reduced the expression of BAX, caspase- 9 , caspase- 3 , and cleaved caspase-3, meanwhile, increased the expression of Bcl-2, then improved neurological functional scores (NFSs), and reduced infarction area in I/R injury rats.

Fourthly, a number of studies have indicated that different rhubarb anthraquinones act together in the treatment of CIS. Qinxiao Guan et al. [36] found that optimized rhubarb aglycone (aloe-emodin: rhein: emodin: chrysophanol:physcion $=50: 76: 38: 105: 68)$ regulated amino acid, energy and lipid metabolic disturbance related to the I/R injury by increasing the plasma levels of lipids, phosphocreatine/creatine, and the urine levels of taurine, tyrosine, $\alpha$-ketoglutaric acid/creatinine, and decreasing the plasma levels of lactate, taurine, glutamate, glycine, methionine/glucose, and the urine levels of choline, glycine, and proline/glucose. Accordingly, rhubarb anthraquinones could alleviate neurological impairment and cerebral infarction area and inhibit neuronal apoptosis in I/R rats. Meanwhile, Li $\mathrm{j}$ et al. [37] reported that rhubarb aglycone reduced thrombolysis-caused brain microvascular basement membrane impairment through decreasing the level of $\operatorname{IgG}$ and increasing the level of type IV collagen (CoLIV) and laminin (LN) and then decreased the intracranial hemorrhage ratio and mortality in cerebral ischemia rats. What is more, Xiangping Lin et al. [38] found 287 differentially expression proteins (DEPs) and 76 overlapping DEPs between model group (MG) versus sham group (SG) and rhubarb group (RG) versus MG with iTRAQ-based proteomics analysis. There were 14 DEPs related pathways including synaptic vesicle cycle, cGMPPKG signaling pathway, amyotrophic lateral sclerosis, longterm potentiation, tuberculosis, and so on. 76 overlapping DEPs are mainly associated with synaptic vesicle cycling. Furthermore, compared with the MG, rhubarb treatment significantly increased the protein expression of Synl and ERK1/2, which are pathway proteins related to synaptic transmission and plasticity [39,40]. Interestingly, a pharmacokinetics study showed that the model group's maximum plasma concentration $\left(\mathrm{C}_{\max }\right)$, half-life $\left(\mathrm{t}_{1 / 2}\right)$, and area under curve $\left(\mathrm{AUC}_{0-\mathrm{t}}\right)$ of aloe-emodin, rhein, emodin, and chrysophanol were remarkably increased, but the total body clearance (CL) values were significantly decreased compared with normal group. These results demonstrated anthraquinones were easier to be absorbed in CIS condition [41].

2.2. Intracerebral Hemorrhage. Plenty of studies have suggested that rhubarb anthraquinones exhibit protective effects in ICH and its underlying mechanisms of action are involved in anti-inflammation, antiapoptosis, and protection of BBB [42-44]. It has been reported that emodin triggered microglia cell apoptosis by increasing the activity of caspase 3/7 and promoted activated microglia cell apoptosis through reducing the level of TNF- $\alpha$ and IL-1 $\beta$. Meanwhile, emodin induced the expression of TRB3 during microglial apoptosis, which is a proapoptotic gene associated with oxidative stress and apoptosis $[45,46]$. Moreover, overexpression of TRB3 induced microglial cell apoptosis and knockdown of TRB3 attenuated the apoptotic effect of emodin [42]. On the other hand, YANG WANG et al. [43] found that rhubarb or its active components (aloe-emodin, rhein, emodin, and chrysophanol) relieved neurological symptoms and attenuated $\mathrm{BBB}$ permeability by enhancing zonula occludens-1 (ZO-1) expression in ICH rats. ZO-1 is a main kind of tight junction proteins, which constitutes an important part of BBB [47]. Similarly, Tang YP et al. [44] suggested rhubarb could maintain $\mathrm{BBB}$ integrity and reduce astrocyte end feet process swelling by inhibiting the expression of AQP-4 gene.

2.3. Traumatic Brain Injury. Many of studies have proved that rhubarb anthraquinones exert therapeutic effects in TBI and its associated mechanisms including anti-inflammation, antiglutamate excitotoxicity, antioxidative stress, and protection of the BBB integrity [48-53]. Yuan Ma et al. [48] found that emodin reduced brain damage and improved behavioral observation by inhibiting the expression and activity of inducible nitric oxide synthase (iNOS) and then consequently attenuated the generation of NO after blastinduced TBI in mice. Interestingly, Jian-Wen Gu et al. [49] reported that emodin inhibited the excitatory postsynaptic potential (EPSP) and markedly improved paired-pulse facilitation (PPF) of the EPSP on CAl pyramidal neurons. Furthermore, the inhibition of the EPSP induced by emodin was blocked by either adenosine deaminase or 8 -CPT, an adenosine A1 receptor antagonist, whereas the inhibitory synaptic transmission was not affected by emodin. The results suggested rhubarb extracts exerted neuroprotective effects by inhibiting glutamate excitotoxicity. Additionally, Lin XZ et al. [54] reported that emodin and rhubarb polysaccharides played the opposite role in brain intracellular $\mathrm{Ca}^{2+}$ level.

On the other hand, Yang Wang and his colleagues [50-52] reported that rhubarb and rhein exhibited protective effects after TBI through inhibiting extracellular regulated kinase (ERK)/matrix metalloproteinase-9 (MMP-9) pathway and reducing oxidative stress; besides, they could reduce brain edema and BBB permeability through inhibiting ERK/MMP9 pathway by preventing activation of gp9lphox subunit of NADPH oxidase induced ROS production in vitro and in vivo [50]. Similarly, another study suggested that oral administration of rhubarb downregulated MMP-9 and upregulated ZO-1 by inhibiting ERK signaling pathway [51]. What is more, rhubarb and rhein also improved the activities of SOD and CAT, increased the level of glutathione (GSH) and the ratio of GSH/glutathione disulfide (GSSG) and decreased the levels of MDA and GSSG in TBI rats [52]. In the end, Wang ZP et al. [53] reported that rheum tanguticum polysaccharides could decrease water content and the level of MDA and improve the activities of $\mathrm{Na}+\mathrm{K}+$ ATPase and total SOD. 
2.4. Brain Tumor. The antitumor effects of rhubarb anthraquinones are mainly focused on the inhibition of brain tumor growth by inducing apoptosis[10, 55-58]. Plenty of in vitro studies have shown danthron can inhibit glioma growth[10,55-57], which is a brain tumor with poor prognosis and usually develops into high-grade malignancies $[15,59]$. Danthron was reported to induce C6 rat glioma cells apoptosis via ROS-associated and mitochondria-mediated pathways, it reduced mitochondrial membrane potential level, released cytochrome $c$, apoptosisinducing factor (AIF), and endonuclease G (Endo G) from mitochondria and increased the levels of caspase-9/3; meanwhile, it also increased the production of ROS and this effect could be reversed by ROS scavenger $\mathrm{N}$-acetylL-cysteine[10].CHIN-CHUNG LIN et al. [55] suggested that danthron inhibited the invasion and migration of glioblastoma multiforme GBM 8401 cells via decreasing the expressions of focal adhesion kinase (FAK), MMP-7, MMP-9, uPA, and Rho-associated kinase 1 (ROCK-1). Glioblastoma is one of the most aggressive and malignant forms of glioma [60]. Similarly, Hsu-Feng Lu et al. [56] found that danthron killed and induced apoptosis of GBM 8401 cells in concentration- and time-dependent manner. The potential mechanism might relate to increasing the levels of ROS, cytosolic $\mathrm{Ca}^{2+}$, caspase-8/9, and Bax, decreasing the levels of mitochondrial membrane potential and procaspase-8/9 proteins, and activating caspase-3/8/9. Besides, the inhibitors of caspase-3/8/9 blocked the activation effect of danthron against these factors. Moreover, the same author reported that danthron induced DNA damage in GBM 8401 cells via decreasing the expression of DNA damage and repair genes such as ataxia-telangiectasia mutated (ATM), ataxia-telangiectasia and Rad3-related (ATR), breast cancer 1, early onset (BRCA-1), 14-3-3 proteins sigma (14-3-3 $\sigma$ ), DNA-dependent serine/threonine protein kinase (DNA-PK), and $\mathrm{O}^{6}$-methylguanine-DNA methyltransferase (MGMT) [57]. On the other hand, aloe-emodin (AE) was reported to inhibited U87MG human glioma cells growth and block U87MG in S and G2/M phase via increasing the protein levels of p53/p21 and decreasing the phosphorylation of AKT as well as inhibiting the expression of CDK2, which is an active protein in the $S$ phase of the cell cycle. Meanwhile AE also induced U87MG apoptosis by reducing the expression of poly (ADP-ribose) polymerase (PARP) and activating Lamin A. In addition, AE markedly reduced the U87MG cell density and tumor size and improved the levels of P53 and caspase $8 / 3$ in vivo [58]. Physcion has been reported to increase the expression of $\alpha 2,8$-sialyltransferase (hST8Sia VI) gene through ERK and p38 MAPK pathways in SK-N$\mathrm{BE}(2)-\mathrm{C}$ human neuroblastoma cells[11]. HST8Sia VI gene is a kind of human sialyltransferase gene, which plays an important part in cell differentiation/adhesion and malignant transformation [61].

2.5. Alzheimer's Disease. AD mainly causes cognitive impairment in the elderly. The neuropathological hallmarks of AD are senile plaques and neurofibrillary tangles containing $\beta$ amyloid protein $(\mathrm{A} \beta)$ [62]. Four of rhubarb anthraquinones (emodin, CHR, rhein, and danthron) exhibit therapeutic effects in AD. First, Tao Liu et al. [63] reported that emodin markedly decreased the cortical neuron's death induced by $\mathrm{A} \beta_{25-35}$, and this effect was blocked by PI3K pathway inhibitor LY294002 or estrogen receptor antagonist ICI182780, but not by U0126, which is an inhibitor of ERK. Besides, emodin increased Bcl-2 expression and the phosphorylation of Akt, and decreased the levels of phosphoJun-N-terminal kinases (JNK) 1/2. At the same time, Yanping Sun et al. [64] suggested that emodin markedly reduced the level of lactate dehydrogenase and inhibited cell viability as well as suppressed the conversion ratio of LC3-I/LC3-II in $\mathrm{A} \beta \mathrm{PP} / \mathrm{PS} 1$ mice and PC12 cells, which has been considered to play a significant role in autophagy and eventually result in cell death [65]. Moreover, emodin significantly reduced the level of LC3-II positive cells in the cortex of A $\beta$ PP/PS1 mice, improved the expression of $\mathrm{Bcl}-2$, and reduced the expressions of Beclin-1 and the class III PI3K (hVps34) induced by $\mathrm{A} \beta_{25-35}$, of which (Beclin-1/hVps34) pathways can promote LC3-I transform to LC3-II [66]. Interestingly, Peng Zeng et al. [67] found that emodin decreased A $\beta$ levels and tau hyperphosphorylation via reducing $\beta$-site amyloid precursor protein-cleaving enzyme 1 (BACE 1) levels and increasing protein phosphatase 2A (PP2A) activity in AD-like rats' hippocampal; meanwhile, it also increased hippocampal neuron numbers and synapse-related proteins, suppressed oxidative stress by regulating MDA/SOD, and decreased DNA methyltransferases $1 / 3 \beta$ levels, which are associated with DNA methylation impairments; moreover, emodin inhibited microglial activation through reducing 5-lipoxygenase (5-LO), IL-6, and TNF- $\alpha$ levels and then improved cognitive function and cerebral microvascular integrity in $\mathrm{AD}$-like rats.

Second, Unbin Chae et al. [68] reported that CHR increased the viability of neuronal cells induced by glutamate in a dose-dependent manner; meanwhile, it inhibited neuronal apoptosis via increasing Bcl-2 expression and decreasing the expressions of Bax and AIF. In addition, CHR reduced ROS levels and prevented mitochondrial fission by suppressing the dephosphorylation of dynamin-related protein 1 (Drp 1) in hippocampal, which is one of the major regions suffered from excessive cell death in $\mathrm{AD}$.

Third, Jiang Liu et al. [69] reported that rhein lysinate, an active component of Rheum tanguticum Maxim, significantly reduced the $\beta$-Amyloid precursor protein (APP) of $\mathrm{AD}$ model rats by improving the expression of sirtuin 1 (SIRT1); it also decreased the expression of TNF- $\alpha$ and IL- 6 , reduced the levels of ROS, and increased the levels of glutathione peroxidase (GSH-px) and SOD in AD rats. Interestingly, two kinds of rhein hybrids have been synthesized as a potential anti-Alzheimer drug candidate [70-73]. One of them is rheinhuprine hybrids; it could alleviate the $\mathrm{A} \beta$-induced synaptic dysfunction, increase the content of synaptic proteins, and induce the long-term potentiation (LTP) in brain slices of C57bl6 mice; meanwhile, it also reduced the levels of $\mathrm{A} \beta$ and improved the levels of mature APP in APP-PS1 transgenic mice. What is more, rhein-huprine hybrids suppressed the activities of human acetylcholinesterase (AChE) and butyrylcholinesterase (BuChE) as well as $\beta$-secretase (BACE-1), of which (BACE-1) function is to promote the synthesis of APP 
to $A \beta[74,75]$ and reduce the aggregation of $A \beta$ in vitro [70]. The latest study reported that rhein-huprine hybrids decreased $A \beta$ levels and memory disorders, induced LTP, and reduced tau phosphorylation and brain inflammation in $\mathrm{AD}$ or $\mathrm{AD}$-like rats [72]. Furthermore, the modified rheinhuprine hybrids also suppressed the activities of $\mathrm{AChE}$ and BACE-1 via reducing oxidative stress and $A \beta /$ tau aggregation [73]. The other one is tacrine-rhein hybrids; research indicated that this hybrid could inhibit AChE-induced $\mathrm{A} \beta$ aggregation; meanwhile, it also had metal-chelating activity with less side effects [71].

Fourth, danthron has been reported to inhibit neuronal injury induced by $\mathrm{A} \beta$ with a concentration-dependent manner; it also suppressed $\mathrm{Fe}^{31+}$-induced oxidative damage via reducing membrane lipid peroxidation in primary cortical cells. What is more, it reduced the damage of neuronal cells induced by sodium nitroprusside and $\mathrm{H}_{2} \mathrm{O}_{2}$ as well as buthionine sulfoximine, an inhibitor of endogenous GSH synthesis [62].

2.6. Depression and Other Nervous System Diseases. Depression is a common and complicated disease; the physiopathology of depression is associated with plenty of bioprocesses including the deficiency of monoamine neurotransmitter activity, the overactivity of hypothalamicpituitary-adrenal axis (HPA axis), and the inflammation and neurodegeneration[16, 76]. Meng Li et al. [77] reported that emodin could reduce serum corticosterone level and improve behavioral performance on depression mice; besides, it also increased the expression of BDNF and glucocorticoid receptor (GR) and relieved the anhedonia symptom by increasing sucrose consumption in depression mice. In addition, Kai Zhang et al. [78] suggested that CHR alleviated the inflammation of LPS-induced depression rats via reducing the levels of IL- $1 \beta / 6$ and TNF- $\alpha$ and attenuated the expression of $\mathrm{P} 2 \mathrm{X} 7 / \mathrm{NF}-\kappa \mathrm{B}$ pathway related proteins including $\mathrm{P} 2 \mathrm{X} 7, \mathrm{p}-$ IKK $\alpha$, p-IKK $\beta$, p-I $\kappa \mathrm{B} \alpha$, and $\mathrm{p}-\mathrm{NF}-\kappa \mathrm{Bp} 65$.

Tao Yang et al. [79] reported that emodin could restore the behavioral disorders and abnormal electroencephalogram (EEG) changes in epileptic rats by attenuating the expressions of multidrug resistance gene 1 (MDR1), cyclooxygenase-2 (COX-2), N-methyl-D-aspartate (NMDA) receptor, and Pglycoprotein [79-83]. At the same time, emodin also has been demonstrated to alleviate the hyperalgesia of chronic constriction injury rats via reducing the expression of $\mathrm{P} 2 \mathrm{X}_{2 / 3}$ receptor, which acts an important part in neuropathic pain $[84,85]$. On the other hand, CHR has been reported to improve cognition function by decreasing the expressions of IL-1 $\beta / 4 / 6$ and TNF- $\alpha$; and it also reduced nerve cell death via inhibiting astrocyte activities in diabetic mice[8]. Besides, CHR reduced the learning and memory damage of leadexposed rats and improved lead-induced mitochondria and rough endoplasmic reticulum injury in hippocampal neurons and capillary endothelial cells. The potential mechanism of this protective effect might relate to increasing the activities of SOD and GSH-Px and decreasing the level of MDA [86]. Moreover, Shu-Jen Chang et al. [87] suggested that rheum palmatum methanol extract, which contains higher levels of emodin, aloe-emodin, chrysophanol, rhein, and physcion than water extract, could kill Japanese encephalitis virus (JEV) and inhibit JEV yields and infectivity.

\section{Conclusion}

Anthraquinones are major bioactive ingredients founded in rhubarb. Although some other Chinese medicinal herbs also contain it, such as Polygonum multiflorum Thunb [22] and Rhizoma Polygoni Cuspidati [24], most of the studies focus on these six anthraquinones (emodin, aloeemodin, CHR, rhein, physcion, and danthron) derived from rhubarb. Emodin, aloe-emodin, and CHR mainly show neuroprotective effects by anti-inflammation, antioxidant stress, and maintaining the integrity of $\mathrm{BBB}$ in CNSD $[8,18,21-24,29-31,34,42,48-50,52,63,67-69,78,86]$. Interestingly, emodin showed contradictory effects on cell apoptosis. Many of studies indicated emodin could inhibit neuronal apoptosis in CIS [22-24], whereas Xueping Zhou et al. [42] reported that emodin induces microglial cell apoptosis in ICH. Moreover, aloe-emodin also induced glioblastoma cell apoptosis [58]. Studies on the neuroprotective effects of rhein are mainly in TBI and $\mathrm{AD}$, the mechanism of which is associated with antiinflammation and antioxidant stress [50, 52]. Danthron basically plays an antitumor role in CNSD [10, 55-57]. From all the in vitro and in vivo experiments currently searchable (Table 1), these bioactive anthraquinones have convincingly demonstrated neuroprotective activities in CNSD and the related pharmacological pathway involving multiple cellular and molecular targets, which indicates these anthraquinones have a broad therapeutic potential in the future.

Most of the studies on the neuroprotective effects of anthraquinone compounds from rhubarb have focused on anthraquinone monomers. The molecular structures of different anthraquinone monomers are very similar (Figure 1); for example, CHR and rhein almost have same molecular structure, except one of CHR's methyl groups is substituted by rhein's carboxyl group; they both inhibited the expression of cleave caspase- 3 and attenuated the activity of SOD in CIS $[29,35]$; however, which effects are stronger is still unknown. The same as emodin and CHR, emodin removes one of hydroxyl group then become CHR; they both demonstrated anti-inflammatory properties in CIS by downregulating the expression of TNF- $\alpha$ and IL-1 $\beta$ [21,30,34], while which ingredient works better remains obscure. There are many other studies reported that anthraquinones or rhubarb has neuroprotective activities as a whole, but whether/how the monomer components interact with each other remains unclear. Therefore, further researches not only need to be carried out in order to explore more neuroprotective mechanisms of rhubarb anthraquinones in CNSD, but also to find out which anthraquinones monomers have the best therapeutic effects and whether/how they could interact with each other.

\section{Conflicts of Interest}

The authors declare that there are no conflicts of interest regarding the publication of this paper. 
TABLE 1: List of the neuroprotective effects of anthraquinones in CNSD.

\begin{tabular}{|c|c|c|c|c|}
\hline Disease & Anthraquinones & Outcomes & Application & Ref. \\
\hline \multirow[t]{11}{*}{ Ischemic stroke } & Emodin & $\begin{array}{l}\text { Improves NDS, reduces BBB permeability } \\
\text { and decreases the infarction area via } \\
\text { inhibiting the expression of } \mathrm{Cx} 43 \text { and AQP4 }\end{array}$ & In vivo & 18 \\
\hline & Emodin & $\begin{array}{l}\text { Improves neurologic symptom evaluation } \\
\text { score, brain water ratio and cerebral } \\
\text { infarction area; inhibits cascade } \\
\text { inflammatory reaction by increasing TGF- } \beta \\
\text { level and depressing the levels of } \\
\text { TNF- } \alpha / \text { IL-1 } \beta / \text { ICAM-1 }\end{array}$ & In vivo & 21 \\
\hline & Emodin & $\begin{array}{l}\text { Enhances behavioral function, against } \\
\text { apoptosis through increasing Bcl-2 } \\
\text { expression and decreasing caspase-3 and } \\
\text { BAX expression; increases BDNF expression } \\
\text { and the phosphorylation of Akt/CREB }\end{array}$ & $\begin{array}{l}\text { In vitroand } \\
\text { In vivo }\end{array}$ & 22 \\
\hline & Emodin & $\begin{array}{c}\text { Inhibits } \mathrm{H}_{2} \mathrm{O}_{2} \text {-induced apoptosis in primary } \\
\text { rat cortical neurons }\end{array}$ & In vitro & 23 \\
\hline & Emodin & $\begin{array}{c}\text { Inhibits neuronal apoptosis and alleviates } \\
\text { the injury of PC12 nerve cells via increasing } \\
\text { the expression of activin A }\end{array}$ & In vitro & 24 \\
\hline & Chrysophanol & $\begin{array}{c}\text { Inhibits NO-induced neuronal death } \\
\text { through attenuating the levels of } \\
\mathrm{NO}_{\mathrm{x}}^{-} / 3-\mathrm{NT} \text {, and decreases cleaved caspase-3 } \\
\text { expression; increases total SOD/MnSOD } \\
\text { activities and inhibits ROS generation }\end{array}$ & In vivo & 29 \\
\hline & Chrysophanol & $\begin{array}{c}\text { Decreases neurological deficits, infarct } \\
\text { volume, brain edema and BBB permeability; } \\
\text { inhibits inflammatory response via reducing } \\
\text { the expression of IL-1 } \beta \text {, caspase- } 1 \text { as well as } \\
\text { NALP3 }\end{array}$ & In vivo & 30 \\
\hline & Chrysophanol & $\begin{array}{c}\text { Improves survival rate, reduces brain tissue } \\
\text { loss, and improves neurological assessment } \\
\text { and motor function; reduces the expression } \\
\text { of TNF- } \alpha \text {, IL- } 1 \beta \text { and NF- } \kappa \text { B p } 65\end{array}$ & In vivo & 34 \\
\hline & Chrysophanol & $\begin{array}{c}\text { Inhibits inflammatory response and } \\
\text { neuronal apoptosis by attenuating the } \\
\text { expression of ER stress-related factors } \\
\text { including GRP78, CHOP, caspase-12 and } \\
\text { I } \kappa \mathrm{B}-\alpha\end{array}$ & In vivo & 31 \\
\hline & Rhein & $\begin{array}{c}\text { Improves NFSs and reduces infarction area; } \\
\text { decreases MDA level and enhances the } \\
\text { activities of SOD/CAT/GSH-Px; reduces the } \\
\text { expression of BAX, caspase- } 9 / 3 \text { and cleaved } \\
\text { caspase-3, and increases the expression of } \\
\text { Bcl-2 }\end{array}$ & In vivo & 35 \\
\hline & $\begin{array}{l}\text { Rhubarb } \\
\text { anthraquinones }\end{array}$ & $\begin{array}{l}\text { Alleviates neurological impairment and } \\
\text { cerebral infarction area, and inhibits } \\
\text { neuronal apoptosis; increases the plasma } \\
\text { levels of lipids, phosphocreatine/creatine } \\
\text { and the urine levels of taurine, tyrosine, } \\
\alpha \text {-ketoglutaric acid/creatinine, and } \\
\text { decreases the plasma levels of lactate, } \\
\text { taurine, glutamate, glycine, } \\
\text { methionine/glucose and the urine levels of } \\
\text { choline, glycine, proline/glucose }\end{array}$ & In vivo & 36 \\
\hline
\end{tabular}


TABle 1: Continued.

\begin{tabular}{|c|c|c|c|c|}
\hline Disease & Anthraquinones & Outcomes & Application & Ref. \\
\hline & $\begin{array}{l}\text { Rhubarb } \\
\text { anthraquinones }\end{array}$ & $\begin{array}{l}\text { Decreases the intracranial hemorrhage ratio } \\
\text { and mortality; reduces brain microvascular } \\
\text { basement membrane impairment through } \\
\text { decreasing the level of IgG and increasing } \\
\text { the levels of CoLIV/LN }\end{array}$ & In vivo & 37 \\
\hline & Rhubarb & $\begin{array}{c}\text { Finds } 287 \text { DEPs and } 76 \text { overlapping DEPs } \\
\text { between MG versus SG and RG versus MG; } \\
\text { the related pathways including synaptic } \\
\text { vesicle cycle, cGMP-PKG signaling pathway, } \\
\text { amyotrophic lateral sclerosis, long-term } \\
\text { potentiation, tuberculosis, and so on; } \\
\text { increases the protein expression of Synl and } \\
\text { ERK1/2 }\end{array}$ & In vivo & 38 \\
\hline & $\begin{array}{l}\text { Rhubarb } \\
\text { anthraquinones }\end{array}$ & $\begin{array}{l}\text { The } \mathrm{C}_{\max }, \mathrm{t}_{1 / 2} \text { and } \mathrm{AUC}_{0-\mathrm{t}} \text { of aloe-emodin, } \\
\text { rhein, emodin and chrysophanol are } \\
\text { increased in CIS condition }\end{array}$ & In vivo & 41 \\
\hline \multirow[t]{3}{*}{$\begin{array}{l}\text { Intracerebral } \\
\text { hemorrhage }\end{array}$} & Emodin & $\begin{array}{c}\text { Triggers microglia cell apoptosis by } \\
\text { increasing the activity of caspase } 3 / 7 \text {; } \\
\text { promotes activated microglia cell apoptosis } \\
\text { by reducing the level of TNF- } \alpha \text { and IL- } 1 \beta \text {, } \\
\text { and induces the expression of TRB3 during } \\
\text { microglial apoptosis }\end{array}$ & In vitro & 42 \\
\hline & $\begin{array}{l}\text { Rhubarb or } \\
\text { rhubarb } \\
\text { anthraquinones }\end{array}$ & $\begin{array}{c}\text { Relieves neurological symptoms and } \\
\text { attenuates BBB permeability by enhancing } \\
\text { ZO-1 expression }\end{array}$ & In vivo & 43 \\
\hline & Rhubarb & $\begin{array}{l}\text { Maintains BBB integrity and reduces } \\
\text { astrocyte end feet process swelling by } \\
\text { inhibiting AQP- } 4 \text { expression }\end{array}$ & In vivo & 44 \\
\hline \multirow[t]{7}{*}{$\begin{array}{l}\text { Traumatic brain } \\
\text { injury }\end{array}$} & Emodin & $\begin{array}{c}\text { Reduces brain damage, improves behavioral } \\
\text { observation by inhibiting the expression and } \\
\text { activity of iNOS, and attenuates the } \\
\text { generation of NO }\end{array}$ & In vivo & 48 \\
\hline & Emodin & $\begin{array}{l}\text { Inhibits the EPSP, improves PPF of the EPSP, } \\
\text { and inhibits glutamate excitotoxicity }\end{array}$ & In vitro & 49 \\
\hline & Rhein and rhubarb & $\begin{array}{l}\text { Reduces brain edema and BBB permeability } \\
\text { through preventing activation of gp9lphox } \\
\text { subunit of NADPH oxidase induced ROS } \\
\text { production; inhibits ERK/MMP-9 pathway }\end{array}$ & $\begin{array}{l}\text { in vivo and in } \\
\text { vitro }\end{array}$ & 50 \\
\hline & Rhubarb & $\begin{array}{l}\text { Down-regulates MMP-9 and up-regulates } \\
\text { ZO-1 by inhibiting ERK signaling pathway }\end{array}$ & in vivo & 51 \\
\hline & Rhein and rhubarb & $\begin{array}{c}\text { Improves the activities of SOD and CAT, } \\
\text { increases the level of GSH and the ratio of } \\
\text { GSH/GSSG, and decreases the levels of } \\
\text { MDA and GSSG }\end{array}$ & in vivo & 52 \\
\hline & $\begin{array}{l}\text { Rheum tanguticum } \\
\text { polysaccharides }\end{array}$ & $\begin{array}{c}\text { Decreases water content and the level of } \\
\text { MDA, and improves the activities of } \\
\mathrm{Na}+\mathrm{K}+\text { ATPase and total SOD }\end{array}$ & in vivo & 53 \\
\hline & Emodin & Regulates the brain intracellular $\mathrm{Ca}^{2+}$ level & In vitro & 54 \\
\hline Brain tumor & Danthron & $\begin{array}{l}\text { Reduces mitochondrial membrane potential } \\
\text { level, releases cytochrome c, AIF and Endo } \\
\text { G from mitochondria, and increases } \\
\text { caspase- } 9 / 3 \text { levels and ROS production }\end{array}$ & in vitro & 55 \\
\hline
\end{tabular}


TABle 1: Continued.

\begin{tabular}{|c|c|c|c|c|}
\hline \multirow[t]{6}{*}{ Disease } & Anthraquinones & Outcomes & Application & Ref. \\
\hline & Danthron & $\begin{array}{l}\text { Inhibits the invasion and migration of GBM } \\
8401 \text { via decreasing the expressions of FAK, } \\
\text { MMP-7, MMP-9, uPA and ROCK-1 }\end{array}$ & in vitro & 56 \\
\hline & Danthron & $\begin{array}{c}\text { Kills GBM } 8401 \text { cells and induces apoptosis } \\
\text { by increasing the levels of ROS, cytosolic } \\
\mathrm{Ca}^{2+} \text {, caspase- } 8 / 9 \text { and Bax, decreasing } \\
\text { mitochondrial membrane potential levels } \\
\text { and pro-caspase- } 8 / 9 \text { protein levels, and } \\
\text { activating caspase- } 3 / 8 / 9\end{array}$ & in vitro & 57 \\
\hline & Danthron & $\begin{array}{l}\text { Induces DNA damage in GBM } 8401 \text { cells via } \\
\text { decreasing the expressions of DNA damage } \\
\text { and repair genes such as ATM, ATR, } \\
\text { BRCA-1, } 14-3-3 \sigma, \text { DNA-PK and MGMT }\end{array}$ & in vitro & 58 \\
\hline & Aloe-emodin & $\begin{array}{l}\text { Inhibits U87MG human glioma cells growth } \\
\text { and blocks U87MG in S and G2/M phase via } \\
\text { increasing the protein level of p53/p21 and } \\
\text { decreasing AKT phosphorylation and CDK2 } \\
\text { expression; induces U87MG apoptosis by } \\
\text { reducing PARP expression and activating } \\
\text { Lamin A, reduces U87MG cell density and } \\
\text { tumor size, and improves the levels of P53 } \\
\text { and caspase } 8 / 3\end{array}$ & $\begin{array}{c}\text { in vivo and in } \\
\text { vitro }\end{array}$ & 59 \\
\hline & Physcion & $\begin{array}{l}\text { Increases the expression of hST8Sia VI } \\
\text { through ERK and p38 MAPK pathways in } \\
\text { SK-N-BE(2)-C human neuroblastoma cells }\end{array}$ & in vitro & 63 \\
\hline \multirow[t]{5}{*}{ Alzheimer's disease } & Emodin & $\begin{array}{c}\text { Decreases } \mathrm{A} \beta_{25-35} \text {-induced neuron death } \\
\text { and the levels of phospho-JNK } 1 / 2, \text { increases } \\
\text { the phosphorylation of Akt and Bcl-2 } \\
\text { expression }\end{array}$ & in vitro & 66 \\
\hline & Emodin & $\begin{array}{c}\text { Inhibits cell viability and the conversion } \\
\text { ratio of LC3-I/LC3-II, reduces the level of } \\
\text { lactate dehydrogenase; decreases the level of } \\
\text { LC3-II positive cells in the cortex of } \\
\text { A } \beta \text { PP/PS1 mice; improves Bcl-2 expression } \\
\text { and reduces the expressions of Beclin-1 and } \\
\text { hVps34 }\end{array}$ & $\begin{array}{c}\text { in vivo and in } \\
\text { vitro }\end{array}$ & 67 \\
\hline & Emodin & $\begin{array}{l}\text { Decreases A } \beta \text { aggregation and tau } \\
\text { hyperphosphorylation via reducing BACE1 } \\
\text { levels and increasing PP2A activity; } \\
\text { increases hippocampal neuron numbers and } \\
\text { synapse-related proteins; suppresses } \\
\text { oxidative stress by down-regulating MDA } \\
\text { and up-regulating SOD, decreases DNA } \\
\text { methyltransferases } 1 / 3 \beta \text { level, inhibits } \\
\text { microglial activation by reducing } 5 \text {-LO, IL-6 } \\
\text { and TNF- } \alpha \text {, and improves cognitive } \\
\text { function and cerebral microvesselar integrity }\end{array}$ & in vivo & 70 \\
\hline & Chrysophanol & $\begin{array}{l}\text { Increases the viability of neuronal cells, } \\
\text { inhibits apoptosis via increasing Bcl-2 } \\
\text { expression and decreasing the expression of } \\
\text { Bax and AIF; reduces ROS levels and } \\
\text { prevents mitochondrial fission by } \\
\text { suppressing the dephosphorylation of Drpl }\end{array}$ & in vitro & 71 \\
\hline & Rhein lysinate & $\begin{array}{l}\text { Reduces APP by improving the expression } \\
\text { of SIRT1, decreases the expressions of } \\
\text { TNF- } \alpha \text { and IL- } 6 \text {, reduces ROS levels and } \\
\text { increases the levels of GSH-px and SOD }\end{array}$ & in vivo & 72 \\
\hline
\end{tabular}


TABLE 1: Continued.

\begin{tabular}{|c|c|c|c|c|}
\hline Disease & Anthraquinones & Outcomes & Application & Ref. \\
\hline & $\begin{array}{l}\text { Rhein-huprine } \\
\text { hybrids }\end{array}$ & $\begin{array}{c}\text { Alleviates the } \mathrm{A} \beta \text {-induced synaptic } \\
\text { dysfunction, increases the content of } \\
\text { synaptic proteins and induces LTP; reduces } \\
\text { the levels of } \mathrm{A} \beta \text {, improves mature APP } \\
\text { levels, suppresses the activities of AChE, } \\
\text { BuChE and BACE-1, and reduces the } \\
\text { aggregation of } \mathrm{A} \beta\end{array}$ & $\begin{array}{l}\text { in vivo and in } \\
\text { vitro }\end{array}$ & 73 \\
\hline & $\begin{array}{l}\text { Rhein-huprine } \\
\text { hybrids }\end{array}$ & $\begin{array}{l}\text { Decreases memory disorders and A } \beta \text { levels, } \\
\text { reduces tau phosphorylation and brain } \\
\text { inflammation, and induces LTP }\end{array}$ & in vivo & 75 \\
\hline & $\begin{array}{l}\text { Rhein-huprine } \\
\text { hybrids }\end{array}$ & $\begin{array}{c}\text { Suppresses the activities of } \mathrm{AChE} \text { and } \\
\text { BACE-1 via reducing oxidative stress and } \\
\mathrm{A} \beta / \text { tau aggregation }\end{array}$ & in vitro & 76 \\
\hline & $\begin{array}{l}\text { Tacrine-rhein } \\
\text { hybrids }\end{array}$ & $\begin{array}{c}\text { Inhibits AChE-induced } \mathrm{A} \beta \text { aggregation, and } \\
\text { shows metal-chelating activity with less side } \\
\text { effects }\end{array}$ & $\begin{array}{l}\text { in vivo and in } \\
\text { vitro }\end{array}$ & 74 \\
\hline & Danthron & $\begin{array}{l}\text { Inhibits neuronal injury, and suppresses } \\
\text { oxidative damage via reducing membrane } \\
\text { lipid peroxidation }\end{array}$ & in vitro & 65 \\
\hline \multirow[t]{2}{*}{ Depression } & Emodin & $\begin{array}{l}\text { Improves behavioral performance, reduces } \\
\text { serum corticosterone level, increases the } \\
\text { expressions of BDNF and GR, and improves } \\
\text { the anhedonia symptom by increasing } \\
\text { sucrose consumption }\end{array}$ & in vivo & 81 \\
\hline & Chrysophanol & $\begin{array}{l}\text { Alleviates inflammation via reducing the } \\
\text { levels of IL- } 1 \beta / 6 \text { and TNF- } \alpha \text {, and attenuates } \\
\text { the expression of P2X7/NF- } \kappa \text { B pathway } \\
\text { related proteins inculding } 22 X 7 \text {, p-IKK } \alpha \text {, } \\
\text { p-IKK } \beta, \mathrm{p}-\mathrm{I} \kappa \mathrm{B} \alpha \text { and } \mathrm{p}-\mathrm{NF}-\kappa \mathrm{B} \mathrm{p} 65\end{array}$ & in vivo & 82 \\
\hline Epilepsy & Emodin & $\begin{array}{l}\text { Restores behavioural disorders and } \\
\text { abnormal EEG changes by attenuating the } \\
\text { expressions of MDR1, COX-2, NMDA } \\
\text { receptor and P-glycoprotein }\end{array}$ & in vivo & 83 \\
\hline Neuropathic pain & Emodin & $\begin{array}{l}\text { Alleviates the hyperalgesia via reducing the } \\
\text { expression of } \mathrm{P}_{2} \mathrm{X}_{2 / 3} \text { receptor }\end{array}$ & in vivo & 88 \\
\hline $\begin{array}{l}\text { Diabetic } \\
\text { encephalopa-thy }\end{array}$ & Chrysophanol & $\begin{array}{l}\text { Improves cognition function by decreasing } \\
\text { the expressions of IL- } 1 \beta / 4 / 6 \text { and TNF- } \alpha \text {, and } \\
\text { reduces nerve cell death via inhibiting } \\
\text { astrocyte activity }\end{array}$ & in vivo & 90 \\
\hline Lead poisoning & Chrysophanol & $\begin{array}{c}\text { Reduces learning and memory damage, } \\
\text { improves mitochondria and rough } \\
\text { endoplasmic reticulum injury, raises SOD } \\
\text { and GSH-Px activities, and decreases MDA } \\
\text { level }\end{array}$ & in vivo & 91 \\
\hline Encephalitis & $\begin{array}{c}\text { Rheum palmatum } \\
\text { methanol extract }\end{array}$ & $\begin{array}{l}\text { kills JEV, and inhibits JEV yields and } \\
\text { infectivity }\end{array}$ & in vitro & 92 \\
\hline
\end{tabular}

\section{References}

[1] Y. Cai, M. Sun, J. Xing, and H. Corke, "Antioxidant phenolic constituents in roots of rheum officinale and rubia cordifolia: structure-radical scavenginq activity relationships," Journal of Agricultural and Food Chemistry, vol. 52, no. 26, pp. 7884-7890, 2004.

[2] Y. Shou-zhong, The Divine Farmers Materia Medica:(A Translation of the Shen Nong Ben Cao Jing), Blue Poppy Press, Boulder, Colorado, 1997.
[3] Q. Huang, G. Lu, H. Shen, M. C. M. Chung, and N. O. Choon, "Anti-cancer properties of anthraquinones from rhubarb," Medicinal Research Reviews, vol. 27, no. 5, pp. 609-630, 2007.

[4] C. P. Commission, Pharmacopoeia of the Peoples Republic of China, Chemical Industry Press, China, 2015.

[5] L. Ma, L. Zhao, H. Hu et al., "Interaction of five anthraquinones from rhubarb with human organic anion transporter 1 (SLC22A6) and 3 (SLC22A8) and drug-drug interaction in rats," Journal of Ethnopharmacology, vol. 153, no. 3, pp. 864-871, 2014. 
[6] X. Dong, J. Fu, X. Yin et al., "Emodin: a review of its pharmacology, toxicity and pharmacokinetics," Phytotherapy Research, vol. 30, no. 8, pp. 1207-1218, 2016.

[7] Y.-X. Zhou, W. Xia, W. Yue, C. Peng, K. Rahman, and H. Zhang, "Rhein: a review of pharmacological activities," Evidence-Based Complementary and Alternative Medicine, vol. 2015, Article ID 578107, 10 pages, 2015.

[8] X. Chu, S. Zhou, R. Sun et al., "Chrysophanol relieves cognition deficits and neuronal loss through inhibition of inflammation in diabetic mice," Neurochemical Research, vol. 43, no. 4, pp. 972983, 2018.

[9] N. Zhang, X. Zhang, X. Liu et al., "Chrysophanol inhibits NALP3 inflammasome activation and ameliorates cerebral ischemia/reperfusion in mice," Mediators of Inflammation, vol. 2014, Article ID 370530, 12 pages, 2014.

[10] S.-M. Chiou, C.-H. Chiu, S.-T. Yang et al., "Danthron triggers ROS and mitochondria-mediated apoptotic death in C6 rat glioma cells through caspase cascades, apoptosis-inducing factor and endonuclease G multiple signaling," Neurochemical Research, vol. 37, no. 8, pp. 1790-1800, 2012.

[11] H. Yoon, H. An, M. Ko et al., "Upregulation of human ST8Sia VI ( $\alpha 2,8$-Sialyltransferase) gene expression by physcion in SK$\mathrm{N}-\mathrm{BE}(2)-\mathrm{C}$ human neuroblastoma cells," International Journal of Molecular Sciences, vol. 17, no. 8, p. 1246, 2016.

[12] A. A. Neuhaus, Y. Couch, G. Hadley, and A. M. Buchan, "Neuroprotection in stroke: T he importance of collaboration and reproducibility," Brain, vol. 140, no. 8, pp. 2079-2092, 2017.

[13] E. J. Benjamin, S. S. Virani, C. W. Callaway et al., "Heart disease and stroke statistics-2018 update: a report from the american heart association," Circulation, vol. 137, no. 12, pp. e67-492, 2018.

[14] G. T. Manley and A. I. R. Maas, "Traumatic brain injury: an international knowledge-based approach," Journal of the American Medical Association, vol. 310, no. 5, pp. 473-474, 2013.

[15] P. Y. Wen and S. Kesari, "Malignant gliomas in adults," The New England Journal of Medicine, vol. 359, no. 5, pp. 492-507, 2008.

[16] S. M. Bentley, G. L. Pagalilauan, and S. A. Simpson, "Major depression," Medical Clinics of North America, vol. 98, no. 5, pp. 981-1005, 2014.

[17] J. Li, J. Zhu, H. Hu et al., "Internationalization of traditional/ complementary medicine products: market entry as medicine," Chinese Medicine, vol. 13, no. 1, p. 50, 2018.

[18] Y. Li, Q.-Q. Xu, C.-S. Shan, Y.-H. Shi, Y. Wang, and G.-Q. Zheng, "Combined use of emodin and ginsenoside Rb1 exerts synergistic neuroprotection in cerebral ischemia/reperfusion rats," Frontiers in Pharmacology, vol. 9, p. 943, 2018.

[19] R. Khatri, A. M. McKinney, B. Swenson, and V. Janardhan, "Blood-brain barrier, reperfusion injury, and hemorrhagic transformation in acute ischemic stroke," Neurology, vol. 79, no. 13, pp. S52-S57, 2012.

[20] R. Brouns and P. P. de Deyn, "The complexity of neurobiological processes in acute ischemic stroke," Clinical Neurology and Neurosurgery, vol. 111, no. 6, pp. 483-495, 2009.

[21] J.-S. Lu, J.-X. Liu, W.-Y. Zhang, S.-W. Liang, D. Wang, and J. Fang, "Preventive effects of Emodin on cerebral ischemia injury and expression of the inflammatory factors in rats with cerebral ischemia," Zhongguo Zhong Yao Za Zhi, vol. 30, no. 24, pp. 19391943, 2005.

[22] S. M. Ahn, H. N. Kim, Y. R. Kim et al., "Emodin from Polygonum multiflorum ameliorates oxidative toxicity in HT22 cells and deficits in photothrombotic ischemia," Journal of Ethnopharmacology, vol. 188, pp. 13-20, 2016.
[23] T. Liu, H.-T. Hu, and Q.-R. Sun, "Neuroprotective effects of emodin on primary rat cortical neurons apoptosis induced by hydrogen peroxide," Journal of Chinese Medicinal Materials, vol. 33, no. 7, pp. 1116-1119, 2010.

[24] H. L. Guo, X. R. Shen, Y. Xu, J. L. Yuan, D. M. Zhao, and W. L. Hu, "Emodin prevents hypoxic-ischemic neuronal injury: Involvement of the activin A pathway," Neural Regeneration Research, vol. 8, no. 15, pp. 1360-1367, 2013.

[25] A. B. Belousov, J. D. Fontes, M. Freitas-Andrade, and C. C. Naus, "Gap junctions and hemichannels: communicating cell death in neurodevelopment and disease," BMC Cell Biology, vol. 18, 1, p. 4, 2017.

[26] Z. Zador, O. Bloch, X. Yao, and G. T. Manley, "Aquaporins: role in cerebral edema and brain water balance," Progress in Brain Research, vol. 161, pp. 185-194, 2007.

[27] H. Ageta, A. Murayama, R. Migishima et al., "Activin in the brain modulates anxiety-related behavior and adult neurogenesis," PLoS ONE, vol. 3, no. 4, p. e1869, 2008.

[28] B. Munz, Y. P. Tretter, M. Hertel, F. Engelhardt, C. Alzheimer, and S. Werner, "The roles of activins in repair processes of the skin and the brain," Molecular and Cellular Endocrinology, vol. 180, no. 1-2, pp. 169-177, 2001.

[29] Y. Zhao, Y. Huang, Y. Fang et al., "Chrysophanol attenuates nitrosative/oxidative stress injury in a mouse model of focal cerebral ischemia/reperfusion," Journal of Pharmacological Sciences, vol. 138, no. 1, pp. 16-22, 2018.

[30] N. Zhang, X. Zhang, X. Liu et al., "Chrysophanol inhibits NALP3 inflammasome activation and ameliorates cerebral ischemia/reperfusion in mice," Mediators of Inflammation, vol. 2014, Article ID 370530, 12 pages, 2014.

[31] Y. Zhao, Y. Fang, H. Zhao et al., "Chrysophanol inhibits endoplasmic reticulum stress in cerebral ischemia and reperfusion mice," European Journal of Pharmacology, vol. 818, pp. 1-9, 2018.

[32] R. Zhou, A. Tardivel, B. Thorens, I. Choi, and J. Tschopp, "Thioredoxin-interacting protein links oxidative stress to inflammasome activation," Nature Immunology, vol. 11, no. 2, pp. 136-140, 2010.

[33] F. S. Sutterwala, Y. Ogura, D. S. Zamboni, C. R. Roy, and R. A. Flavell, "NALP3: A key player in caspase-1 activation," Journal of Endotoxin Research, vol. 12, no. 4, pp. 251-256, 2006.

[34] Y. Zhao, Y. Fang, J. Li et al., "Neuroprotective effects of Chrysophanol against inflammation in middle cerebral artery occlusion mice," Neuroscience Letters, vol. 630, pp. 16-22, 2016.

[35] Q. Zhao, X. Wang, A. Chen et al., "Rhein protects against cerebral ischemic/reperfusioninduced oxidative stress and apoptosis in rats," International Journal of Molecular Medicine, vol. 41, no. 5, pp. 2802-2812, 2018.

[36] Q. Guan, S. Liang, Z. Wang, Y. Yang, and S. Wang, " ${ }^{1}$ H NMRbased metabonomic analysis of the effect of optimized rhubarb aglycone on the plasma and urine metabolic fingerprints of focal cerebral ischemia-reperfusion rats," Journal of Ethnopharmacology, vol. 154, no. 1, pp. 65-75, 2014.

[37] J. Li, J. Liu, D. Wang et al., "Effects of rhubarb aglycone combined with thrombolysis on brain microvascular basement membrane impairment in rats with thrombus-occluded cerebral ischemia," Zhongguo Zhong Yao Za Zhi, vol. 35, no. 21, pp. 2908-2911, 2010.

[38] X. Lin, T. Liu, P. Li et al., "iTRAQ-based proteomics analysis reveals the effect of rhubarb in rats with ischemic stroke," BioMed Research International, vol. 2018, Article ID 6920213, 13 pages, 2018. 
[39] R. J. Kelleher, A. Govindarajan, H.-Y. Jung, H. Kang, and S. Tonegawa, "Translational control by MAPK signaling in longterm synaptic plasticity and memory," Cell, vol. 116, no. 3, pp. 467-479, 2004.

[40] F. Cesca, P. Baldelli, F. Valtorta, and F. Benfenati, "The synapsins: key actors of synapse function and plasticity," Progress in Neurobiology, vol. 91, no. 4, pp. 313-348, 2010.

[41] S.-X. Feng, J.-S. Li, L.-B. Qu, Y.-M. Shi, and D. Zhao, "Comparative pharmacokinetics of five rhubarb anthraquinones in normal and thrombotic focal cerebral ischemia-induced rats," Phytotherapy Research, vol. 27, no. 10, pp. 1489-1494, 2013.

[42] X. Zhou, L. Wang, M. Wang et al., "Emodin-induced microglial apoptosis is associated with TRB3 induction," Immunopharmacology and Immunotoxicology, vol. 33, no. 4, pp. 594-602, 2011.

[43] Y. Wang, F. Peng, G. Xie et al., "Rhubarb attenuates blood-brain barrier disruption via increased zonula occludens-1 expression in a rat model of intracerebral hemorrhage," Experimental and Therapeutic Medicine, vol. 12, no. 1, pp. 250-256, 2016.

[44] Y. P. Tang, D. F. Cai, and J. Liu, "Research on acting mechanism of rhubarb on aquaporin-4 in rats with blood-brain barrier injury after acute cerebral hemorrhage," Zhongguo Zhong Xi Yi Jie He Za Zhi, vol. 26, no. 2, pp. 152-156, 2006.

[45] Y. S. Kanwar, “TRB3: An oxidant stress-induced pseudokinase with a potential to negatively modulate MCP-1 cytokine in diabetic nephropathy," American Journal of Physiology-Renal Physiology, vol. 299, no. 5, pp. F963-F964, 2010.

[46] M. Salazar, A. Carracedo, Í. J. Salanueva et al., "Cannabinoid action induces autophagy-mediated cell death through stimulation of ER stress in human glioma cells," The Journal of Clinical Investigation, vol. 119, no. 5, pp. 1359-1372, 2009.

[47] C. Yang, K. E. Hawkins, S. Doré, and E. Candelario-Jalil, "Neuroinflammatory mechanisms of blood-brain barrier damage in ischemic stroke," American Journal of Physiology-Cell Physiology, vol. 316, no. 2, pp. C135-C153, 2019.

[48] Y. Ma, X. Xia, J.-M. Cheng et al., "Emodin inhibits inducible nitric oxide synthase in a rat model of craniocerebral explosive injury," Neurochemical Research, vol. 39, no. 9, pp. 1809-1816, 2014.

[49] J.-W. Gu, H. Hasuo, M. Takeya, and T. Akasu, "Effects of emodin on synaptic transmission in rat hippocampal CA1 pyramidal neurons in vitro," Neuropharmacology, vol. 49, no. 1, pp. 103-111, 2005.

[50] Y. Wang, X. Fan, T. Tang et al., "Rhein and rhubarb similarly protect the blood-brain barrier after experimental traumatic brain injury via gp91phox subunit of NADPH oxidase/ ROS/ERK/MMP-9 signaling pathway," Scientific Reports, vol. 6, no. 1, 2016.

[51] Z. Yang, R. Fan, P. Sun et al., "Rhubarb attenuates cerebral edema via inhibition of the extracellular signal-regulated kinase pathway following traumatic brain injury in rats," Pharmacognosy Magazine, vol. 14, no. 53, pp. 134-139, 2018.

[52] X. Xu, H. Lv, Z. Xia et al., "Rhein exhibits antioxidative effects similar to Rhubarb in a rat model of traumatic brain injury," BMC Complementary and Alternative Medicine, vol. 17, no. 1, article no. 140, 2017.

[53] Z. P. Wang, L. Liu, Q. B. Mei et al., "Protective effect of Rheum tanguticum polysaccharides (RTP) on traumatic brain injury in rats," Zhongguo Zhong Yao Za Zhi, vol. 28, no. 10, pp. 974-976, 2003.

[54] X. Z. Lin and Z. H. Jin, "Effects of sennosides, rhubarb polysaccharides and emodin on the cytoplasmic free calcium in isolated rat brain cells," Acta Pharmaceutica Sciencia, vol. 30, no. 4, pp. 307-310, 1995.

[55] C.-C. Lin, J.-T. Chen, J.-S. Yang et al., "Danthron inhibits the migration and invasion of human brain glioblastoma multiforme cells through the inhibition of mRNA expression of focal adhesion kinase, rho kinases-1 and metalloproteinase-9," Oncology Reports, vol. 22, no. 5, pp. 1033-1037, 2009.

[56] H.-F. Lu, H.-L. Wang, Y.-Y. Chuang et al., "Danthron induced apoptosis through mitochondria- and caspase-3-dependent pathways in human brain glioblastoma multiforms GBM 8401 cells," Neurochemical Research, vol. 35, no. 3, pp. 390-398, 2010.

[57] H.-F. Lu, T.-Y. Lai, T.-C. Hsia et al., "Danthron induces DNA damage and inhibits DNA repair gene expressions in GBM 8401 human brain glioblastoma multiforms cells," Neurochemical Research, vol. 35, no. 7, pp. 1105-1110, 2010.

[58] A. Arcella, M. A. Oliva, S. Staffieri et al., "Effects of aloe emodin on U87MG glioblastoma cell growth: In vitro and in vivo study," Environmental Toxicology, vol. 33, no. 11, pp. 1160-1167, 2018.

[59] A. Giese and M. Westphal, "Treatment of malignant glioma: a problem beyond the margins of resection," Journal of Cancer Research and Clinical Oncology, vol. 127, no. 4, pp. 217-225, 2001.

[60] M. Tamborini, E. Locatelli, M. Rasile et al., "A combined approach employing chlorotoxin-nanovectors and low dose radiation to reach infiltrating tumor niches in glioblastoma," ACS Nano, vol. 10, no. 2, pp. 2509-2520, 2016.

[61] R. Schauer, "Sialic acids as regulators of molecular and cellular interactions," Current Opinion in Structural Biology, vol. 19, no. 5, pp. 507-514, 2009.

[62] Y. S. Kwon, J. Y. Koh, D. K. Song et al., "Danthron inhibits the neurotoxicity induced by various compounds causing oxidative damages including beta-amyloid (25-35) in primary cortical cultures," Biological \& Pharmaceutical Bulletin, vol. 27, no. 5, pp. 723-726, 2004.

[63] T. Liu, H. Jin, Q.-R. Sun, J.-H. Xu, and H.-T. Hu, "Neuroprotective effects of emodin in rat cortical neurons against $\beta$-amyloidinduced neurotoxicity," Brain Research, vol. 1347, pp. 149-160, 2010.

[64] Y.-P. Sun and J.-P. Liu, "Blockade of emodin on amyloid- $\beta$ 25 -35-induced neurotoxicity in A $\beta$ PP/PS1 mice and PC12 cells through activation of the class III phosphatidylinositol 3-kinase/beclin-1/B-cell lymphoma 2 pathway," Planta Medica, vol. 81, no. 2, pp. 108-115, 2015.

[65] S. Zhi-Kun, Y. Hong-Qi, W. Zhi-Quan, P. Jing, H. Zhen, and C. Sheng-Di, "Erythropoietin prevents PC12 cells from betaamyloid-induced apoptosis via PI3K/Akt pathway," Translational Neurodegeneration, vol. 1, no. 1, p. 7, 2012.

[66] X. Li and Z. Fan, "The epidermal growth factor receptor antibody cetuximab induces autophagy in cancer cells by downregulating HIF- $1 \alpha$ and $\mathrm{Bcl}-2$ and activating the Beclin 1/hVps34 complex," Cancer Research, vol. 70, no. 14, pp. 59425952, 2010.

[67] P. Zeng, Y. Shi, X. M. Wang et al., "Emodin rescued hyperhomocysteinemia-induced dementia and Alzheimer's disease-like features in rats," International Journal of Neuropsychopharmacology, 2018.

[68] U. Chae, J.-S. Min, H. H. Leem et al., "Chrysophanol suppressed glutamate-induced hippocampal neuronal cell death via regulation of dynamin-related protein 1-dependent mitochondrial fission," Pharmacology, vol. 100, no. 3-4, pp. 153-160, 2017.

[69] J. Liu, G. Hu, R. Xu et al., "Rhein lysinate decreases the generation of $\beta$-amyloid in the brain tissues of Alzheimer's 
disease model mice by inhibiting inflammatory response and oxidative stress," Journal of Asian Natural Products Research, vol. 15, no. 7, pp. 756-763, 2013.

[70] E. Viayna, I. Sola, M. Bartolini et al., "Synthesis and multitarget biological profiling of a novel family of rhein derivatives as disease-modifying anti-Alzheimer agents," Journal of Medicinal Chemistry, vol. 57, no. 6, pp. 2549-2567, 2014.

[71] S. Y. Li, N. Jiang, S. S. Xie, K. D. Wang, X. B. Wang, and L. Y. Kong, "Design, synthesis and evaluation of novel tacrinerhein hybrids as multifunctional agents for the treatment of Alzheimer's disease," Organic \& Biomolecular Chemistry, vol. 12, no. 5, pp. 801-814, 2014.

[72] F. G. Serrano, C. Tapia-Rojas, F. J. Carvajal et al., "Rhein-huprine derivatives reduce cognitive impairment, synaptic failure and amyloid pathology in abetappswe/ps-1 mice of different ages," Current Alzheimer Research, vol. 13, no. 9, pp. 1017-1029, 2016.

[73] F. J. Pérez-Areales, N. Betari, A. Viayna et al., "Design, synthesis and multitarget biological profiling of second-generation antiAlzheimer rhein-huprine hybrids," Future Medicinal Chemistry, vol. 9, no. 10, pp. 965-981, 2017.

[74] P. C. May, R. A. Dean, S. L. Lowe et al., "Robust central reduction of amyloid-beta in humans with an orally available, nonpeptidic beta-secretase inhibitor," The Journal of Neuroscience, vol. 31, no. 46, pp. 16507-16516, 2011.

[75] S. Butini, S. Brogi, E. Novellino et al., "The structural evolution of $\beta$-secretase inhibitors: A focus on the development of smallmolecule inhibitors," Current Topics in Medicinal Chemistry, vol. 13, no. 15, pp. 1787-1807, 2013.

[76] M. Maes, R. Yirmyia, J. Noraberg et al., "The inflammatory \&amp;amp; neurodegenerative (I\&ND) hypothesis of depression: leads for future research and new drug developments in depression," Metabolic Brain Disease, vol. 24, no. 1, pp. 27-53, 2009.

[77] M. Li, Q. Fu, Y. Li, S. Li, J. Xue, and S. Ma, "Emodin opposes chronic unpredictable mild stress induced depressivelike behavior in mice by upregulating the levels of hippocampal glucocorticoid receptor and brain-derived neurotrophic factor," Fitoterapia, vol. 98, pp. 1-10, 2014.

[78] K. Zhang, J. Liu, X. You et al., "P2X7 as a new target for chrysophanol to treat lipopolysaccharide-induced depression in mice," Neuroscience Letters, vol. 613, pp. 60-65, 2016.

[79] T. Yang, B. Kong, Y. Kuang et al., "Emodin plays an interventional role in epileptic rats via multidrug resistance gene 1 (MDR1)," International Journal of Clinical and Experimental Pathology, vol. 8, no. 3, pp. 3418-3425, 2015.

[80] M. Białecka, G. Hnatyszyn, J. Bielicka-Cymerman, and M. Droździk, "The effect of MDR1 gene polymorphism in the pathogenesis and the treatment of drug-resistant epilepsy," Neurologia i Neurochirurgia Polska, vol. 39, no. 6, pp. 476-481, 2005.

[81] M. Seven, B. Batar, S. Unal, G. Yesil, A. Yuksel, and M. Guven, "The drug-transporter gene MDR1 C3435T and G2677T/A polymorphisms and the risk of multidrug-resistant epilepsy in Turkish children," Molecular Biology Reports, vol. 41, no. 1, pp. 331-336, 2014.

[82] T. Ishikawa, A. Sakurai, H. Hirano, A. Lezhava, M. Sakurai, and Y. Hayashizaki, "Emerging New Technologies in Pharamcogenomics: Rapid SNP detection, molecular dynamic simulation, and QSAR analysis methods to validate clinically important genetic variants of human ABC Transporter ABCB1 (P-gp/MDR1)," Pharmacology \& Therapeutics, vol. 126, no. 1, pp. 69-81, 2010.
[83] M. Kaya, A. J. Becker, and C. Gürses, "Blood-brain barrier, epileptogenesis, and treatment strategies in cortical dysplasia.," Epilepsia, vol. 53, pp. 31-36, 2012.

[84] Y. Gao, H. Liu, L. Deng et al., "Effect of emodin on neuropathic pain transmission mediated by $\mathrm{P} 2 \mathrm{X} 2 / 3$ receptor of primary sensory neurons," Brain Research Bulletin, vol. 84, no. 6, pp. 406-413, 2011.

[85] C. Kennedy, T. S. Assis, A. J. Currie, and E. G. Rowan, "Crossing the pain barrier: $\mathrm{p} 2$ receptors as targets for novel analgesics," The Journal of Physiology, vol. 553, no. 3, pp. 683-694, 2003.

[86] J. Zhang, C. L. Yan, S. Wang, Y. Hou, G. P. Xue, and L. Zhang, "Chrysophanol attenuates lead exposure-induced injury to hippocampal neurons in neonatal mice," Neural Regeneration Research, vol. 9, no. 9, pp. 924-930, 2014.

[87] S.-J. Chang, S.-H. Huang, Y.-J. Lin, Y.-Y. Tsou, and C.-W. Lin, "Antiviral activity of Rheum palmatum methanol extract and chrysophanol against Japanese encephalitis virus," Archives of Pharmacal Research, vol. 37, no. 9, pp. 1117-1123, 2014. 


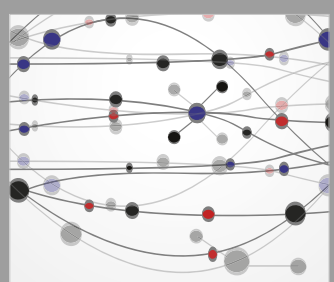

The Scientific World Journal
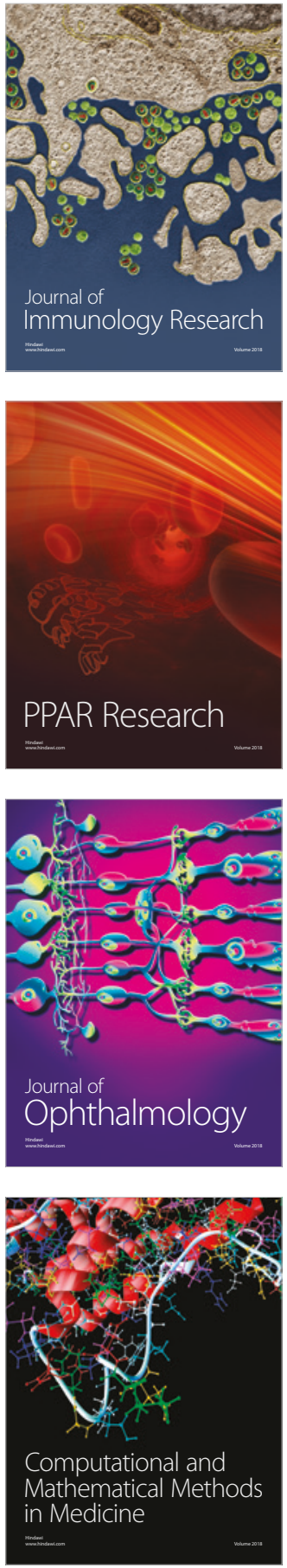

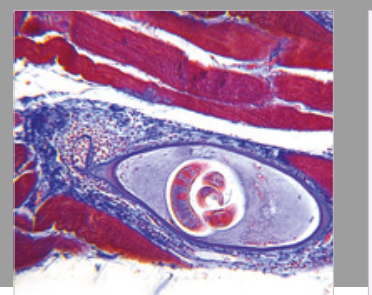

Gastroenterology Research and Practice

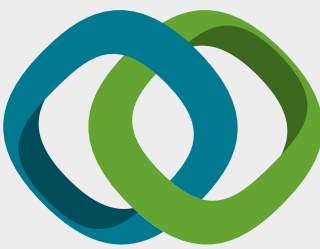

\section{Hindawi}

Submit your manuscripts at

www.hindawi.com
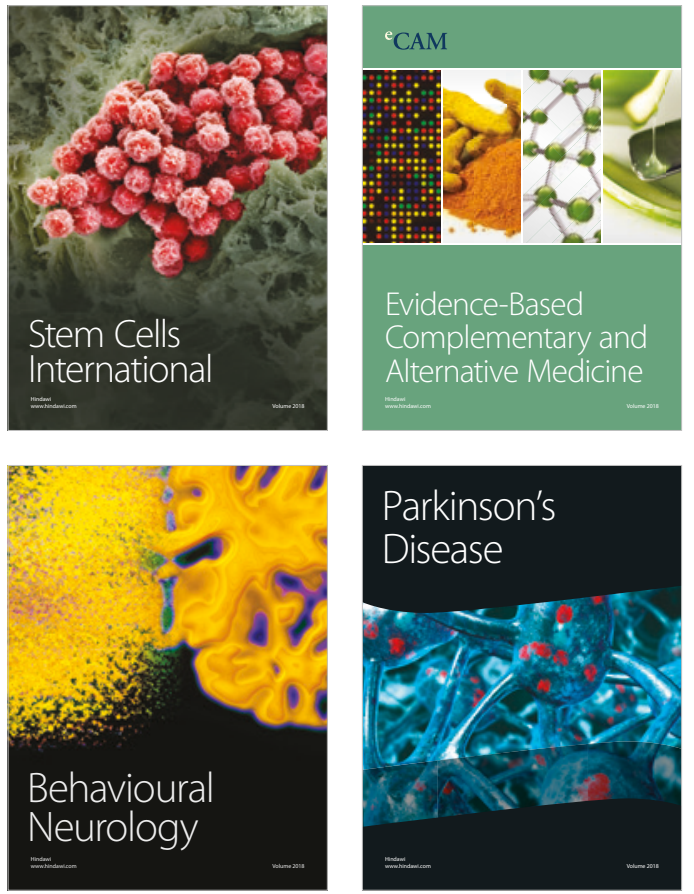

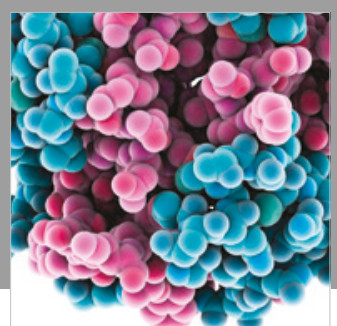

ournal of

Diabetes Research

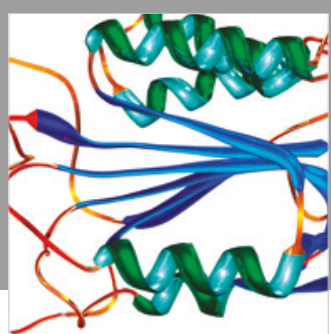

Disease Markers
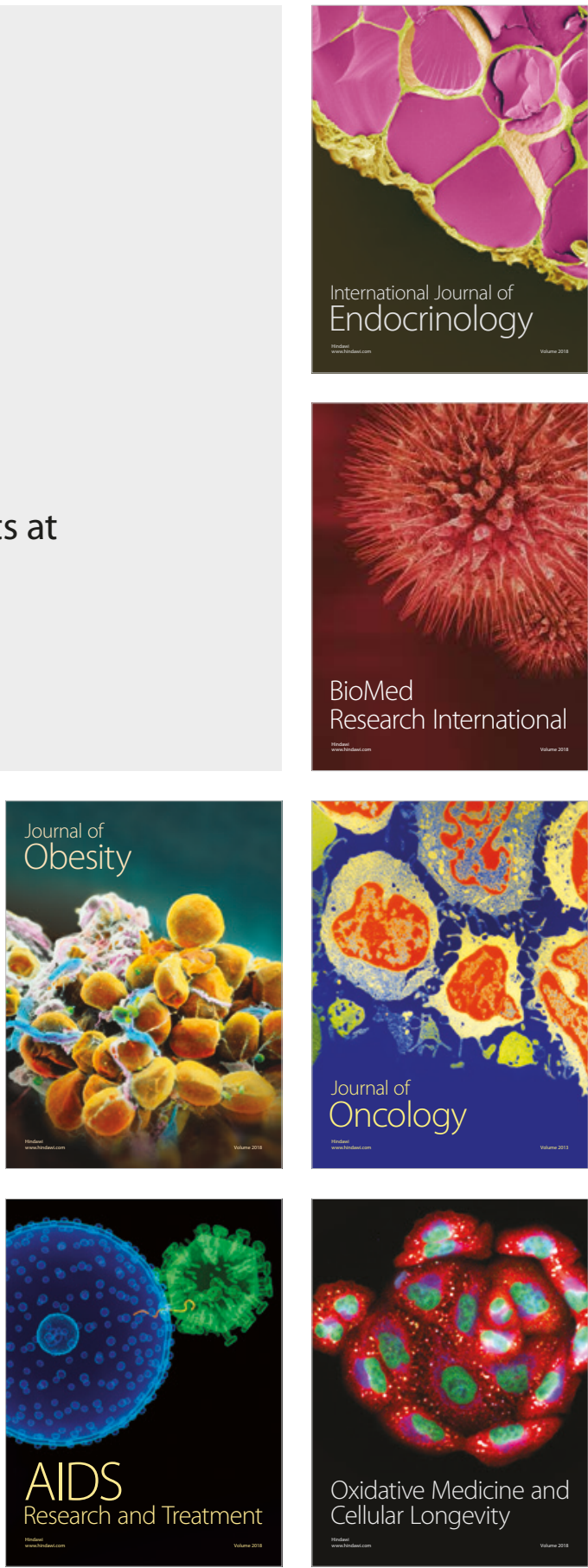